\title{
Incidence of Silent Oestrus and an Investigation of Reproductive Status in Crossbred Cows under Field Conditions of Assam
}

\author{
D. Bharali ${ }^{1}$ *, K.C. Deka ${ }^{2}$, B.C. Deka ${ }^{2}$, K.C. Nath ${ }^{2}$, \\ R.K. Biswas ${ }^{2}$, L.J. Dutta ${ }^{2}$ and B.K. Sarmah ${ }^{3}$ \\ ${ }^{1}$ Livestock Research Station, AAU, Mondira, Kamrup, Assam, India \\ ${ }^{2}$ Department of Animal Reproduction, Gynaecology \& Obstetrics, ${ }^{3}$ Department of Animal \\ Physiology, College of Veterinary Science, AAU, Khanapara, Guwahati-781022, Assam, India \\ *Corresponding author
}

\section{A B S T R A C T}

\section{Keywords}

Crossbred cows, Postpartum, Perrectum, Silent oestrus, Incidence

Article Info

Accepted:

15 April 2019

Available Online:

10 May 2019
The present study was carried out in a total of 673 postpartum crossbred cows of first to fifth lactations maintained under stall fed conditions at different Government and private farms from Kamrup Metro, Cachar and Udalguri district of Assam. All the postpartum crossbred cows were examined per rectum to determine the reproductive status based on the owner's history and the incidence of cows with silent oestrus was worked out. Results revealed that a total of 86 crossbred cows (12.78\%) reported to be anestrous were identified as silent oestrus on the basis of presence of either uterine tone or corpus luteum or Graafian follicle on clinico-gynaecological examination. The district-wise incidence of silent oestrus was found to be 14.29, 10.08 and 14.25 per cent in Kamrup Metro, Cachar and Udalguri district respectively. Reproductive status of the crossbred cows other than anoestrus investigated were pregnant, recently calved, repeat breeder, true anoestrus, chronic cervicitis, metritis, ovaro-bursal adhesion, cystic ovary and normal oestrus with the percentage frequencies of $11.44,8.02,22.88,26.11,2.67,11.00,0.30,0.44$ and 4.31 respectively when estimated out of the total number of postpartum cows.

\section{Introduction}

Silent oestrus causes huge economic losses to the dairy farmers by increasing calving-toconception interval. Mostly the new dairy entrepreneurs are affected specially in semi urban and rural areas. Silent oestrus is clinically characterized by failure to exhibit behavioural signs of oestrus, though the animal is surprisingly normal. Follicular development and ovulation occur normally in animals affected with silent oestrus. Silent oestrus is common during the post pubertal period in heifers and early postpartum (30 to 120 days) in high yielding dairy cows. Progesterone secreted from regressing CL of previous cycle potentiates the action of oestrogen and seems to favour the manifestation of oestrus in next cycle (King et al., 1976; Allrich, 1994). Thus, lack of progesterone priming results in sub-oestrus or silent oestrus. Other causes of sub oestrus are 
genetic factor, heat stress, nutritional deficiencies, overweight, foot lesions and aging. But most common cause considered for silent oestrus is the failure of oestrus detection. Oestrus detection failure is the most common management factor contributing to higher incidence of silent oestrus in high yielding cows. Proper and timely detection of oestrus is a very much necessary tool in planned breeding programme for economic development of a dairy herd.

\section{Materials and Methods}

The present study was carried out in a total of 673 postpartum crossbred cows of first to fifth lactations maintained under stall fed conditions at different Government and private farms from three districts of Assam viz. Kamrup Metro, Cachar and Udalguri. The postpartum cross bred cows which failed to exhibit oestrus symptoms till 90 days after parturition were investigated and the cows which had palpable structures on either of the ovary or had genital changes like that of an oestrus cow were categorized as silent estrous cows.

The postpartum breedable cows under the present study were surveyed at different Government and private farms from the above mentioned districts of Assam and the incidence of cows with silent oestrus was worked out on the basis of owners' reports and clinico-gynaecological examination.

\section{Results and Discussion}

During the period of study a clinicogynaecological survey was conducted in different dairy pockets of Kamrup Metro, Cachar and Udalguri districts of Assam to find out the incidence of silent oestrus condition in crossbred cattle. A total of 673 crossbred postpartum cows were examined per rectum to determine the reproductive status based on the farm or owner's history or record, genital changes and incidence of silent oestrus condition was worked out (Table 1). Under this study only cows of first to fifth lactation with milk yield from 8-20 litres were investigated.

Results of the present study revealed that a total of 86 crossbred cows (12.78\%) reported to be an oestrus were identified as silent oestrus on the basis of presence of either uterine tone or corpus luteum or Graafian follicle on per rectal examination. The district-wise incidence was 14.29, 10.08 and 14.25 per cent in Kamrup Metro, Cachar and Udalguri district respectively. The incidence of silent estrous cows under the present study was similar with the report of Arthur et al., (1989) and Iyer et al., (1992) but it was less than that reported by Kakar et al., (1997) and higher than that reported by Bonia and Baishya (2011).

The reproductive status other than silent oestrus under the present study i.e. pregnant, recently calved, repeat breeder, true anoestrus, chronic cervicitis, metritis, ovarobursal adhesion, cystic ovary and normal oestrus was recorded as $11.44,8.02,22.88$, $26.11,2.67,11.00,0.30,0.44$ and 4.31 per cent, respectively (Table 2). The highest incidence was recorded as true anoestrus followed by repeat breeder.

The findings of the present study was in agreement with that of Singha et al., (1987), Yadav et al., (2004), Khair et al., (2013) and Khan et al., (2016) however, differed from the findings of Iyer et al., (1992), Dutta and Sinha (2012), Chand et al., (2013), Hadusa et al., (2013) and Maji and Sarma (2013). The variation in the incidence found under the present study might be due to the effect of level of nutrition, environmental stress and genetic makeup of the animals. 
Table.1 Incidence of silent oestrus in crossbred cows investigated in three districts of Assam

\begin{tabular}{|l|c|c|c|c|}
\hline \multirow{2}{*}{ Number } & \multicolumn{3}{|c|}{ District } & Total \\
\cline { 2 - 5 } & Kamrup Metro & Cachar & Udalguri & \\
\hline Village & 7 & 21 & 27 & 55 \\
\hline Cow & 56 & 238 & 379 & 673 \\
\hline Silent oestrus detected & 8 & 24 & 54 & 86 \\
\hline Incidence of silent oestrus (\%) & 14.29 & 10.08 & 14.25 & 12.78 \\
\hline
\end{tabular}

Table.2 Reproductive status of crossbred cows investigated in three districts of Assam ( $n=673)$

\begin{tabular}{|c|l|c|c|}
\hline Sl. No. & Reproductive status & Number of animals & Percentage \\
\hline $\mathbf{1}$ & Silent oestrus & 86 & 12.78 \\
\hline $\mathbf{2}$ & Pregnant & 77 & 11.44 \\
\hline $\mathbf{3}$ & Recently calved & 54 & 8.02 \\
\hline $\mathbf{4}$ & Repeat breeder & 154 & 22.88 \\
\hline $\mathbf{5}$ & True anoestrus & 176 & 26.11 \\
\hline $\mathbf{6}$ & Chronic cervicitis & 18 & 2.67 \\
\hline $\mathbf{7}$ & Metritis & 74 & 11.00 \\
\hline $\mathbf{8}$ & Ovaro-bursal adhesion & 2 & 0.30 \\
\hline $\mathbf{9}$ & Cystic ovary & 3 & 0.44 \\
\hline $\mathbf{1 0}$ & Normal oestrus & 29 & 4.31 \\
\hline
\end{tabular}

In conclusion, it was very clear that silent oestrus condition is a major cause of reproductive failure in Kamrup Metro, Cachar and Udalguri districts of Assam. But this condition is always treated as anoestrus in field condition. Therefore necessary steps should be taken by the veterinarians to create awareness cum training programme on "silent oestrus and their management" amongst dairy farmers' for economic betterment.

\section{References}

Allrich, R.D. 1994. Endocrine and neural control of estrus in dairy cows. J. Dairy Sci., 77: 2738-2744.

Arthur, G. H., Noakes, D. E. and Pearson, H. 1989. Veterinary Reproduction and Obstetrics. pp. 354-355. $6^{\text {th }}$ Edn. The English Language Book Society, Bailliere, Tindal, London.

Bonia, K. K. and Baishya, N. 2011.
Therapeutic management versus biological constituents of sub- oestrous crossbred cows of Asom. Indian J. Anim. Sci., 81 (4): 362-66.

Chand, S., Meena, B. S., Kumar, A., Yadav, S. P. and Soni, S. K. 2013. Incidence of reproductive disorders in dairy animals of Rajasthan. Indian Vet. J. 90: 34-36.

Dutta, J.C. and Sinha, S. 2012. Study on incidence of reproductive disorders in Jersey crossbred cows. Proceeding of the XXVIII Annual Convention and National Symposium of ISSAR on "Addressing animal reproductive stresses through biotechnological tools". 21-23 November 2012. C.V.Sc., AAU, Khanapara, Guwahati, pp- 127.

Hadush, A., Abdella, A. and Regassa F. 2013. Major prepartum and postpartum reproductive problems of dairy cattle in Central Ethiopia. Journal of Veterinary Medicine and Animal Health, 5:118- 
123.

Iyer, C.P.N., Nair, K.P., Sudarsan, V., Madhvan, E., Mothai, E., Nair, M.S., Vijay, K.V. and Joseph, M. 1992. Reproductive disorders of crossbred cows in Kerala. Indian J. Anim. Reprod., 13: 64-68.

Kakar, M. A., Rasool, G. and Ahmad, F. 1997. Clinical incidence of reproductive disorders in crossbred cows in the province of Balochistan. Pakistan Vet. J., 17 (1): 9-12.

Khair, A., Alam, M. M., Rahman, A. K. M. A., Islam, M. T., Azim, A and Chowdhury, E. H. 2013. Incidence of reproductive and production diseases of cross-bred dairy cattle in Bangladesh. Bangl. J. Vet. Med., 11 (1): 31-36.

Khan, M. H., Manoj, K. and Pramod, S. 2016. Reproductive disorders in dairy cattle under semi-intensive system of rearing in North- Eastern India. Vet. World., 9: 512-518.

King, G.J., Hurnik, J.F. and Robertson, H.A. 1976. Ovarian function and estrus activity in dairy cows during early lactation. J. Dairy Sci., 42: 688 -92.

Maji, A.K. and Samanta, A. 2013.Analysis of incidence of infertility in cattle of Howrah district in West Bengal, India. Anim. Med. Res., 3 (2): 154-158.

Sinha, B.P., Sinha, S.N. and Singh, B. 1987. Incidence of anestrus in crossbred cattle in field and farm conditions. $L i v$. $A d v$., 12(32): 43-48.

Yadav, Y. P. Singh, A.P. Kunj, V. Akhtar, M.H. Roy, G.P. and Singh, C. 2004. Study on incidence of anestrous and blood biochemical constituents in noncyclic and cyclic crossbred cows. Indian J. Anim. Reprod., 25: 116-119.

\section{How to cite this article:}

Bharali, D., K.C. Deka, B.C. Deka, K.C. Nath, R.K. Biswas, L.J. Dutta and Sarmah, B.K. 2019. Incidence of Silent Oestrus and an Investigation of Reproductive Status in Crossbred Cows under Field Conditions of Assam. Int.J.Curr.Microbiol.App.Sci. 8(05): 1922-1925. doi: https://doi.org/10.20546/ijcmas.2019.805.222 